\title{
Human capital of school-age population in West Sumatera: measurement and determinant
}

\author{
Firlan*; Werry Darta Taifur; Indrawari \\ Faculty of Economics, Universitas Andalas, Indonesia \\ *To whom correspondence should be addressed. Email: sabananeha@gmail.com.
}

\begin{abstract}
Information on human capital, especially for school- age population is still limited. Most of Indicators of human capital only consider the dimensions of education, while human capital is formed by various dimensions not only education. Recent human capital measurement is displayed in macro level so that difficult to analys in micro level. Based on recent condition of human capital information, this study aims to measure the human capital of the school-age population of 7-18 years old using the fuzzy set approach by considering several dimensions of human capital investment and analysis the determinant. The data source is from West Sumatera Socio-Economic Survey that held by National Bureau of Statistic in March 2017. Measurement human capital of 9,950 samples of school age population shows that urban areas have higher human capital than the rural areas. Internal factors, household and spouse characteristics such as income, parent education and occupation have impact in their children human capital. External factors such as subsidies and rural-urban development inequality also have impact and tend to be larger than internal factor. The strategy of increasing human capital under conditions of limited resources can be achieved by increasing the index of indicators which have greatest weight and also reducing development inequality between urban and rural areas. The other policy is to realize growth economic that have positive impact to entire society. In terms of methodology, this approach can be adapted to regional conditions, the development of theory and related research. Adjustments can be made at the stage of selecting investment indicators, data types and weight of indicator.
\end{abstract}

Keywords: Human capital, School-aged population, Fuzzy set approach

JEL classification: 015 , I25

\section{INTRODUCTION}

Human capital is an important part of economic growth. This has been empirically proven by Mankiw, Romer \& Weil (1992) by adding human capital to the Solow growth model. The result of this model explains that human capital investment has a positive and significant effect on the economic growth of many countries.

The measurement of human capital is important as a consideration for policy making, especially for Indonesia entering demographic bonus. Demographic bonus is a population phenomenon where the ratio of productive population to unproductive population (dependency ratio) is at lowest point. This phenomenon will occur between 2020 and 2030, especially for the province of West Sumatera, it is predicted to occur in 2025 with dependency ratio about 50.07 (BPS, 2012). 
Furthermore, preparing to face the demographic bonus, it is important to ensure that the productive population is a population with high human capital. Schoolage population play an important role in this matter. One reason is that they will become a workforce after attending school. In addition, the formation of good human capital in the school-age population is one of the keys to breaking the poverty chain (Taifur, 2005). Poor households that invest well in human capital such as adequate education and quality and good health have the opportunity to get out of poverty when their children enter the workforce

Unfortunately, a comprehensive indicator of human capital is not yet available for productive population, especially the school-age population. The Human Development Index (HDI), Human Capital Index (HCI), School Participation Rate (SPR) or Net Enrollment Rate (NER) are also not enough to explain the current state of human capital of school-age population. In addition, these indicators are measured only through an educational approach and presented on macro level. Research by Liu (2003), Bagby, de Walque \& Kazianga (2012), Blandin \& Herrington (2018) are some examples of research that make education as form of human capital investment. Whereas according to Becker (1962) human capital investment is very broad in scope, not only education and health, but also every action that can affect income in the future.

Some other dimensions such as information technology can support educational achievement (Bulman \& Fairlie, 2016). Individual with good education and expert in using information technology will certainly have higher human capital than individual just good in the education dimension. This shows that information technology can increase human capital so that it can be categorized as a form of human capital investment.

According to Christian (2017) the measurement of human capital can be done at least through three approaches. Expenditure, income, and indicator approaches. The indicator approach is considered easier to use than other approaches in the context of data availability. This approach will calculate human capital through indicators of various forms of human capital investment.

Human capital is multidimensional (Thamma-Apiroam,2015). The indicator approach will produce different sizes between indicators from various investment dimensions. For example, the value of average years of schooling will differ with health dimension indicators such as the live insurance ownership.

Aggregation among indicators values is needed to provide a more meaningful measurement. One method of aggregation is the fuzzy set approach introduced by Zadeh (1965). So far, fuzzy set approach method has been used in multidimensional poverty index measurements. This method will combine measures in various dimensions into one measure in the form of an index in $[0 ; 1]$.

Besides measure human capital, it is important to review it's determinant in order to contribute in policy maker that support increasing human capital. Many study was conducted show that income still the dominant variable that affect human capital espescially in macro analysis. Brata (2002) show that GNP percapita had positive effect on human development index and also confirm by Setiawan \& Hakim (2013), they found that GNP had positive effect on human development in Indonesia while negative effect from tax and economy crisis. In micro level studys such as was conducted by Liu (2003), Yang (2008), Dang \& Rogers (2016), Qin, Wang \& Zhuang (2016) and Blandin \& Herrington (2018) shows that household characteristic such as income or consumption, parent education and occupation affect human capital of their children. 
Important role of income not exist in west sumatera. It can be proven by looking the interaction between GDRP and HDI. The fact shows that the regency with high GDRP not always have high HDI than regency with low GDRP. It indicate that income in macro level not the only one factor that affect human capital and it could be the hypothesis in micro level.

Finally, this study will measure human capital of school-age population by considering several dimensions of human capital investment in west sumatera using fuzzy set approach and also review it's determinant using regression analysis.

\section{METHODS}

This study use National Socio-Economic Survey (SUSENAS) microdata held by National Bureau of Statistic (BPS) in March 2017. This data allows analysis in regency or municipality level.

Data processing method or index measurement is using fuzzy set approach. This method was first used by Cerioli \& Zani (1990) to measure poverty from a multidimensional perspective. Then this method is explained in detail by Costa (2002). The difference between applied this method in poverty and human capital just in dimensions.

The unit of analysis is individual or population aged 7-18 years old. Then it is aggregated into regency or municipality level. Suppose there is $n$ population aged 7-18 years and is the number of indicators of investment dimensions that are taken into account, and for example $k$ is the set of individual who invest in human capital, then the index of human capital from individual $i$ can be written as:

$$
\mu_{A}(i)=\frac{\sum_{j=1}^{k} z_{i j} w_{j}}{\sum_{j=1}^{k} w_{j}}
$$

Where $z_{i j}$ is membership function $i$ in dimension $j$ and $w_{j}$ is weight of dimension $j$. The membership function $z_{i j}$ can be written as:

$$
z_{i j}=\left\{\begin{array}{c}
1, x \geq x^{\prime} \\
0, x \leq x^{\prime \prime} \\
\frac{x-x^{\prime}}{x^{\prime}-x^{\prime \prime}}, x^{\prime}<x<x^{\prime \prime}
\end{array}\right.
$$

Where $x$ is the data of indicator of dimension $j$ and $x^{\prime}, x^{\prime \prime}$ is criteria of invest or not in dimension $j$.

Membership function can be interpreted as individual membership degrees to become members of set $A$ (individual who invest). For example if someone is not attending in school then it is called not invest in education, then the degree of membership in set $A$ (education dimension) is 0 (not member $\mathrm{A}$ ). If he attends school and the school level is matching to age, the degree of membership is 1 (member A perfectly). The degree of membership is between 0 and 1 if age is not matching with the school level. This relationship also applies to other dimension indicators based on the its membership function.

Weight $w$ for each dimension indicator determined by comparing individuals who meet the investment criteria on a dimension indicator with a population. The more individuals invest in a dimension indicator it can be interpreted as the more important the dimension indicator and bigger weight obtained. Investment criteria can be seen in Table 1. 
Whereas, the household human capital index is the average of the children human capital index owned by household and for the regency or municipality with shchool-age population denoted by $i$, the human capital index is written:

$\mu_{A}(k a b / k o t a)=\frac{1}{n} \sum_{i=1}^{n} \mu_{A}(i)$

In this study there are eight indicators that compile the index, they are individual pure participation (IPP), health insurance, not smoking activities, internet use, sources of drinking water, lighting sources, computer use and cooking water sources (Table 1). Full details of the types of indicator data can be seen in Table 5 (Appendix).

Education has long been recognized as one of the human capital investments. . Healthy insurance and non-smoking behavior are also investments because they have a positive impact on human capital formation, this was stated by Cohodes, Grossman, Kleiner, \& Lovenheim (2014) and Allo, Sukartini \& Saptutyningsih (2018) . Internet use, drinking water sources and types of lighting source also have a positive impact on human capital, each of which is shown by the results of Bulman \& Fairlie (2016); Beach, Ferrie, Saavedra, \& Troesken (2014)) and Bridge, Adhikari, \& Fontenla (2016) so that they are categorized as human capital investment.

Table 1. Characteristics of human capital investment indicators

\begin{tabular}{|c|c|c|c|c|}
\hline Dimension & Indicators & $\begin{array}{c}\text { Data } \\
\text { (value) }\end{array}$ & Membership function & $\begin{array}{l}\text { Investment } \\
\text { criteria }\end{array}$ \\
\hline Education & IPP & $\begin{array}{l}\text { Numeric } \\
(1-18)\end{array}$ & $z_{i j}=\left\{\begin{array}{c}1, x \leq 6 \\
0, x \geq 18 \\
\frac{18-x}{18-6}, 6<x<18\end{array}\right.$ & $\begin{array}{l}\text { If Attendace } \\
\text { Schooling }\end{array}$ \\
\hline \multirow[b]{2}{*}{ Health } & $\begin{array}{l}\text { Health } \\
\text { Insurance }\end{array}$ & $\begin{array}{l}\text { Categorical } \\
(1 . \text { Yes, } 0 . \text { No) }\end{array}$ & $z_{i j}=\left\{\begin{array}{l}1, x=1 \\
0, x=0\end{array}\right.$ & $\begin{array}{l}\text { If Have Health } \\
\text { Insurance }\end{array}$ \\
\hline & $\begin{array}{l}\text { Not Smoking } \\
\text { Behavior }\end{array}$ & $\begin{array}{l}\text { Categorical } \\
(1 . \text { Yes, } 0 . \text { No) }\end{array}$ & $z_{i j}=\left\{\begin{array}{l}1, x=1 \\
0, x=0\end{array}\right.$ & If Not Smoking \\
\hline \multirow{3}{*}{ Housing } & $\begin{array}{l}\text { Lighting } \\
\text { Source }\end{array}$ & $\begin{array}{l}\text { Categorical } \\
(1-4)\end{array}$ & $z_{i j=}\left\{\begin{aligned} 1, x & =3 \\
0, x & =1 \\
\frac{x-1}{3-1}, 1 & <x<3\end{aligned}\right.$ & If Source in 1-3 \\
\hline & $\begin{array}{l}\text { Drinking } \\
\text { Water Source }\end{array}$ & $\begin{array}{l}\text { Categorical } \\
(1-12)\end{array}$ & $z_{i j}=\left\{\begin{array}{c}1, x \leq 4 \\
0, x \geq 11 \\
\frac{11-x}{11-4}, 4<x<11\end{array}\right.$ & If Source in 1-3 \\
\hline & $\begin{array}{l}\text { Cooking } \\
\text { Water Source }\end{array}$ & $\begin{array}{l}\text { Categorical } \\
(1-12)\end{array}$ & $z_{i j}=\left\{\begin{array}{c}1, x \leq 4 \\
0, x \geq 11 \\
\frac{11-x}{11-4}, 4<x<11\end{array}\right.$ & If Source in 1-3 \\
\hline \multirow[t]{2}{*}{$\begin{array}{l}\text { Information } \\
\text { Technology }\end{array}$} & Internet Usage & $\begin{array}{l}\text { Numeric } \\
(0-4)\end{array}$ & $z_{i j}=\left\{\begin{aligned} 1, x & =4 \\
0, x & =0 \\
\frac{x-0}{4-0}, 0 & <x<4\end{aligned}\right.$ & If Using Internet \\
\hline & $\begin{array}{l}\text { Computer } \\
\text { Usage }\end{array}$ & $\begin{array}{l}\text { Categorical } \\
(1 . \text { Yes, } 0 . \text { No) }\end{array}$ & $z_{i j}=\left\{\begin{array}{l}1, x=1 \\
0, x=0\end{array}\right.$ & $\begin{array}{l}\text { If Using } \\
\text { Computer }\end{array}$ \\
\hline
\end{tabular}


Regression analysis with OLS method is used in order reach the second aim that is to determine the variables that affect the human capital. The model that will be estimated as following:

$$
\begin{aligned}
& \text { HCI }=\beta_{0}+\beta_{1} Y+\beta_{2} \text { Fedu }+\beta_{3} \text { Medu }+\beta_{4} \text { Hoccu }+\beta_{5} \text { Hstatus }+\beta_{6} \text { Hsize }+ \\
& \beta_{7} G s u b+\beta_{8} R U+\varepsilon
\end{aligned}
$$

We also interest to review effect of education inequality of parent to their children human capital. We adding dummy variabel "gap" into the model than (4) will be the following:

$$
\begin{aligned}
& H C I=\beta_{0}+\beta_{1} Y+\beta_{2} F e d u+\beta_{3} \text { Medu }+\beta_{4} \text { Hoccu }+\beta_{5} \text { Hstatus }+\beta_{6} \text { Hsize }+ \\
& \beta_{7} G s u b+\beta_{8} R U+G a p 2+G a p 3+\varepsilon
\end{aligned}
$$

Independent variables obtained from several previous studies such as Liu (2003), Yang (2008), Dang \& Rogers (2016), Qin, Wang \& Zhuang (2016), Thakurata \& D'souza (2017), Wang (2018) and Blandin \& Herrington (2018). Althought dependent variable of that research little different with this research but it still relevant to use it's independent variables.

\section{RESULTS AND DISCUSSION}

\section{School-age human capital}

Processing data from 9,950 school-age population (7-18 years old) placed the Mentawai Islands district as the lowest regency with a human capital index of 0.611. Pariaman municipality is the region with the highest index of 0.873 . In general, urban areas have a higher index than the district area, this can be caused by the availability of more adequate education and health facilities and supporting facilities. However, if the index is decomposed into its constituent indicators, each regency or municipality has its own advantages and disadvantages. Composite index and dimension indicators index can be seen in Table 4 (Appendix).

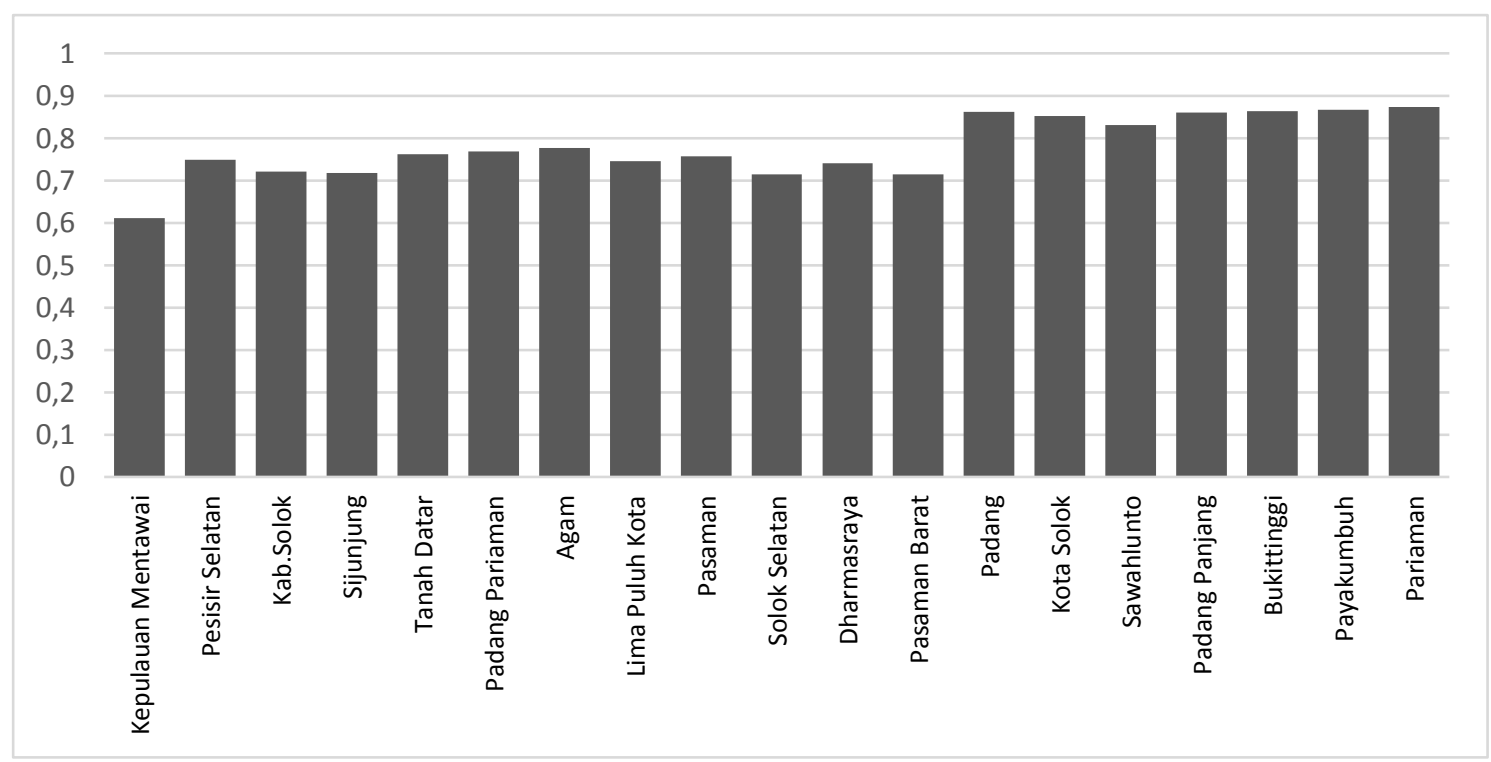

Figure 1. Human capital index of school-age population of West Sumatera by regency and municipality 2017

The magnitude of the weight affects the total index formed. If an area has a low index in an indicator with a large weight it will affect the low total index. The results 
showed that non-smoking activity had the largest weight of 0.97 then education 0.95 , electricity source 0.84 , health insurance 0.60 , drinking water source 0.51 , cooking water source 0.38 , internet use and computer use 0.37 and 0.33 respectively.

Indicator weight is a flexible component. Various methods and justifications can be used to determine their value. In addition to the relative weighting method, the alkirefoster method can also be used. Alkire \& Foster (2011) in forming a multidimensional poverty index that provides the same weight for all dimensions. Furthermore, indicators weight is obtained by dividing the dimension weight by the number of indicators in that dimension. The use of different weight gives a different total index, the relative weight giving the index value tends to be higher than the alkire-foster weight (Table 3, Appendix).

Indicator indices with binary data ( 0 and 1$)$ can be interpreted as a comparison of investing households (1) or those who do not invest (0) to the population. For example index of health insurance indicator in the Mentawai Islands are 0.72 . This means that $72 \%$ of the population already has health insurance, as well as the indicator of smoking activity.

Human capital index by indicators, for West Sumatera there are two indicators are still low, they are health insurance, internet and computer use. Index of health insurance indicator is 0.601 , which means that 60.1 percent of the school-age population has health insurance $^{1}$. The index on the indicator of internet use is 0.215 and computer use is 0.327 which means that it is still far (low) from 1 (perfect value).

Regional groupings according to the human capital index category can be done by determining the intervals of each category. In this study each region will be grouped into four categories, they are low, medium, high and very high. The category interval is obtained from the averages of fisrt, second dan third quantile of all indicators. This method also used by UNDP in classifying countries based on HDI (UNDP, 2018). The category is low if index small than 0.638 , medium if between 0.638 and 0.689 , height between $0.690-0.785$ and very high if index more than 0.785 .

The use of data in the formation of this index is still dominated by categorical data. Only the dimensions of education with IPP indicator are purely quantitative data. The use of categorical data results index tend to less varied. Conversely, quantitative data will provide more varied index because the data tends to be different for each household and has a larger data interval.

The implication of low school-age human capital is they will difficult to get pefect result from human capital investment in general after graduate from college and entrance into labour market. But if they get the perfect human capital in age 7-18 it could predict that they will get good human capital accumalation in college and perfect human capital in the last human capital investment.

\section{Determinant of school-age human capital}

The determinant of human capital of school-age population consists of direct determinants and indirect determinants. The direct determinant is a variable that directly affects the index if the variable experiences a change in value. This direct determinant is a variable used in index calculation and is deterministic. The eight indicators used in calculating the index are direct determinants. If an increase in population has health insurance, the human capital index will increase and so to other indicators. In addition, the weighting scale is also a direct determinant. Changes in the weight of each indicator

\footnotetext{
${ }^{1}$ If indicator index come from binary data, it can be interpret in persentage
} 
will also have a direct effect on the human capital index. Last, the membership function, if the upper and lower limit of membership function is changed, will have a direct impact on the index size.

Indirect determinants of the index are external variables that are not used in calculations and are stochastic. The results of the regression in Table 2 show that internal household variables such as income, parental education and head occupation have a positive effect on the human capital of their children. While the external variables that affect human capital of school-age population are government intervention and ruralurban areas.

Table 2. Regression result

\begin{tabular}{|c|c|c|}
\hline Variables & $\begin{array}{c}\text { Human Capital Index } \\
\text { (Model 1) }\end{array}$ & $\begin{array}{c}\text { Human Capital Index } \\
\text { (Model 2) }\end{array}$ \\
\hline Constant & $\begin{array}{r}0.6891 \\
(0.0067)\end{array}$ & $\begin{array}{r}0.6838 \\
(0.0075)\end{array}$ \\
\hline Income & $\begin{array}{l}2.36 \times 10^{-8 * * * *} \\
\left(1.87 \times 10^{-9}\right)\end{array}$ & $\begin{array}{l}2.35 \times 10^{-8 * * * *} \\
\left(1.87 \times 10^{-9}\right)\end{array}$ \\
\hline Fedu & $\begin{array}{l}0.0029 * * * \\
(0.0004)\end{array}$ & $\begin{array}{l}0,0018 * * \\
(0.0008)\end{array}$ \\
\hline Medu & $\begin{array}{l}0.0031 * * * \\
(0.0004)\end{array}$ & $\begin{array}{l}0,0042 * * * \\
(0.0008)\end{array}$ \\
\hline Hoccu & $\begin{array}{l}-0.0181 * * * \\
(0.0029)\end{array}$ & $\begin{array}{l}-0,0180 * * * \\
(0.0029)\end{array}$ \\
\hline Hstatus & $\begin{array}{l}0.0064 * * * \\
(0.0028)\end{array}$ & $\begin{array}{l}0,0065^{* *} \\
(0.0028)\end{array}$ \\
\hline Hsize & $\begin{array}{r}0.0013 \\
(0.0008)\end{array}$ & $\begin{array}{r}0,0013 \\
(0.0008)\end{array}$ \\
\hline Gsub & $\begin{array}{l}0.0137 * * * \\
(0.0027)\end{array}$ & $\begin{array}{l}0,0137 * * * \\
(0.0027)\end{array}$ \\
\hline UR & $\begin{array}{l}0.0542 * * * \\
(0.0028)\end{array}$ & $\begin{array}{l}0,0541^{* * *} \\
(0.0028)\end{array}$ \\
\hline Gap 2 & - & $\begin{array}{r}0,0058 \\
(0.0041)\end{array}$ \\
\hline Gap 3 & - & $\begin{array}{r}0,0100 \\
(0.0065)\end{array}$ \\
\hline F-Test & 0.0000 & 0.000 \\
\hline Breusch-Pagan Test & 0.5436 & 0.5387 \\
\hline $\mathrm{N}$ & 4,554 & 4,554 \\
\hline
\end{tabular}

Notes: Standard error in parentheses

Model 1 regression exclude years of schooling gap of parent, Model 2 regression include years of schooling gap of parent.

$* * p<0.05, * * * p<0.01$

The effect of income is not too large on human capital. This is possible because not all dimensions of human capital calculation are closely related to income. For example, electricity and internet use are also influenced by government and private policies in 
providing electricity and internet networks. But this finding confirm Liu (2003); Yang (2008); Dang \& Rogers (2016); Leu, Chen \& Chen, (2016); Qin, Wang \& Zhuang (2016) and Blandin \& Herrington (2018) that show positive effect of income in children human capital.

Internal household factors such as parental education show a positive effect, this confirms several previous studies such as Dang \& Rogers (2016). Human capital index will increase about 0.0029 if year of schooling father increase one year and 0.0031 if year of schooling increase one year. The possible reason to explain this is parent attempt to make sure their children have human capital especially education at least the same with him. Further, parent education inequality did not show the effect as shown by Blandin \& Herrington (2018).

The head occupation in the agricultural sector tends to have children with lower human capital than other. It possible because most of people in agricultural sector live in rural area which have less public fasilities. The position of head in the formal sector tends to have children with higher human capital than the informal sector. People in formal sector have better acsess to public fasilites than other, it could be seen in Table 5 (Appendix) and this finding confirm research by Liu (2003).

Household size did not affect human capital of children. It is different with most previous research that had conducted by Akresh, Bagby, de Walque \& Kazianga (2012), Dang \& Rogers (2016) and Blandin \& Herrington (2018). They had found that household size have negative impact on human capital of children. This finding similar to Taifur (2005) who show that household size did not affect poverty status.

Government intervention or subsidies has a positive effect on human capital. It help households that are less able to access human capital investment facilities. Most of household human capital investment like other household consumption such as food and durable goods consumption. Household income is used first to basic need consumption, subsidies make them able to consume beyond it such in education and health. So that low income household still able to invest in human capital. It confirm several previous research such Thakurata \& D'souza (2017) and Wang (2018) that shows that government subsidies have positive impact on human capital.

Development inequality between urban and rural areas has the greatest impact among all variables. The urban area has a higher index of 0.0542 compared to rural areas. It could make senses because urban have complete fasilities support human capital such as education, health, information technology and housing than rural area. Further, urban population especially school-age population get advantage of this condition. This is confirm findings from Qin, Wang \& Zhuang (2016), they show that children who live in urban area had education and health higher than urban area. This condition also confirm Taifur (2005) that convey development inequality between urban and rural lead deceleration on poverty reduction.

\section{CONCLUSIONS AND RECOMMENDATIONS}

\section{Conclusions}

The municipality area is still higher in the human capital index of school-age population than the regency. This is caused by a number of indicators are closely related to the availability of public facilities and infrastructure which in the urban areas are more advanced than the districts. This is show the negative impact from development inequality between municipality and regency. 
It can be concluded that the education dimension with the IPP indicator is almost perfect with 0.925 . However, the supporting indicators are still left behind. Such as the use of the internet and computers that have not been optimal, especially for the district.

The presence of this human capital index can complement the indicators of human capital such as HDI, HCI, School Participation Rates and other indicators especially indicator in micro level. Although the calculation still allows changes, this index can be a consideration for the government in formulating policies.

Income is still variable which have impact on human capital especially on schoolage human capital although the impact is not too large. Household characteristics such as parent education, head occupation beyond agriculture and position in formal sector has positive impact on human capital. Further, external factor such subsidies and living location also have impact and tend to larger impact than other variables.

\section{Recommendations}

This index is formed by micro unit analysis such as individual or household so that probably to hold an analysis based on individual or household. In addition, each step of the calculation allows it to be changed and modified according to the theory, research area or previous underlying research. Some recommendations for further research and the policy are as follows:

First is the data source. This study is dominant using categorical data such as data on ownership of health insurance, smoking activities, sources of drinking water and types of lighting, but it does not rule out the possibility of using numerical data. Using numerical data will make the index more varied and can maximize the fuzzy set approach

Second is the investment dimension. In general the education and health dimensions are most often analyzed. However, there are other dimensions and indicators that can be considered. Dimensions and indicators can adjust to the development of the theory and the latest research as well as the investment habits of the area under study.

Next, the part that can be modified is the indicator weight. Weight has an important role because it will determine the contribution of each indicator in forming an index. This study uses the relative weight of each indicator on the population. Weight can also be determined by considering the proportion of expenditure of an indicator to all household expenses or using Alkire-Foster method that was discussed earlier.

The policy that can be taken in order to increase the human capital index based on direct determinant is to encourage each index compiler indicator to be better. However, in general, constraints on limited resources will be encountered. So in this context an increase in the human capital index can be focused on indicators with the largest weight because it will have a greater impact on the increase in the total index. Reduce development inequality between urban and rural areas could be taken because this inequality also impacts the inequality of the human capital. Economic growth that have positive impact to all levels of society could increase household income and also increase the school-age human capital, this is because economic growth is not always give a positive impact especialy in reduce poverty (Taifur, 2012). The positive impact of government subsidies give the signal that it should be continued and held in right household.

\section{REFERENCES}

Akresh, R., Bagby, E., de Walque, D., \& Kazianga, H. (2012). Child Ability and Household Human Capital Investment Decisions in Burkina Faso. Economic 
Development and Cultural Change, 61(1), 157-186. https://doi.org/10.1086/ 666953

Alkire, S., \& Foster, J. (2011). Counting and multidimensional poverty measurement. Journal of Public Economics, 95(7-8), 476-487. https://doi.org/10.1016/j.jpubeco. 2010.11.006

Allo, A. G., Sukartini, N. M., \& Saptutyningsih, E. (2018). Smoking Behavior and Human Capital Investment : Evidence from Indonesian Household. Jurnal Ilmu Ekonomi, 7(4), 233-246.

BPS. (2012). Analisis Statistik Sosial Bonus Demografi dan Pertumbuhan Ekonomi. Jakarta: BPS

Beach, B., Ferrie, J., Saavedra, M., \& Troesken, W. (2014). Typhoid Fever, Water Quality, and Human Capital Formation. NBER Working Paper Series.

Becker, G. S. (1962). Investmen In Human Capital : A Theoretical Analysis. Journal of Political Economy, 9-49.

Blandin, A., \& Herrington, C. (2018). Family Structure, Human Capital Investment, and Aggregate College Attainment. Mimeo, Virginia Commonwealth University.

Brata, A. G. (2002). Pembangunan Manusia dan Kinerja Ekonomi Regional di Indonesia. Jurnal Ekonomi Pembangunan, 7(2), 113-122.

Bridge, B. A., Adhikari, D., \& Fontenla, M. (2016). Electricity, income, and quality of life. The Social Science Journal, 53(1),33 - 39

Bulman, G., \& Fairlie, R.W. (2016). Technology and Education : Computers, Software, and The Internet. NBER Working Paper Series. Retrieved from http://www.nber.org/papers/w22237

Cerioli, A., \& Zani, S. (1990). A Fuzzy Approach to The Measurement of Poverty. Conference paper, Income and Wealth Distribution, Inequality and Poverty, 272 284

Christian, M. S. (2017). Net Investment and Stocks of Human Capital in the United States, 1975-2013. International Productivity Monitor, (33), 128-149.

Cohodes, S., Grossman, D., Kleiner, S., \& Lovenheim, M. F. (2014). The Effect of Child Health Insurance Access on Schooling: Evidence From Public Insurance Expansions. NBER Working Paper Series.

Costa, M. (2002). A Multidimensional Approach To The Measurement Of Poverty. IRISS Working Paper Series.

Dang, H.A.H., \& Rogers, F.H. (2016). The decision to invest in child quality over quantity: Household size and household investment in education in vietnam. World Bank Economic Review, 30(1), 104-142. https://doi.org/10.1093/wber/lhv048

Leu, C.H., Chen, K.M., \& Chen, H.H. (2016). A multidimensional approach to child poverty in Taiwan. Children and Youth Services Review, 66, 35-44. https://doi.org/10.1016/j.childyouth.2016.04.018

Liu, Z. (2003). The Economic Impact and Determinants of Investment in Human and Political Capital in China. Economic Development and Cultural Change, 51(4), 823-849. Retrieved from http://www.journals.uchicago.edu/doi/10.1086/375570

Mankiw, G.N., Romer, D., \& Weil, D.N. (1992). A Contribution to the Empirics of Economic Growth. The Quarterly Journal of Economics, 107(2), 407 - 437

Qin, X., Wang, T., \& Zhuang, C.C. (2016). Intergenerational transfer of human capital and its impact on income mobility: Evidence from China. China Economic Review, 38, 306-321. https://doi.org/10.1016/j.chieco.2014.10.005

Setiawan, M.B., \& Hakim, A. (2013). Indeks Pembangunan Manusia Indonesia. Jurnal 
Economia, 9, 18-26.

Taifur, W.D. (2005). Kemiskinan Mengikut Sektor Pekerjaan dan Daerah di Provinsi Sumatera Barat. Universiti Malaya.

Taifur, W.D. (2012). Kebijakan Pembangunan yang Berpihak Kepada Penduduk Miskin. Jurnal Riset Akuntansi Dan Bisnis, 12(2), 233-252.

Thakurata, I., \& D'souza, E. (2017). Child labour and human capital in developing countries - A multi-period stochastic model. Economic Modelling, 68(C), 1-15. https://doi.org/10.1016/j.econmod.2017.09.006

Thamma-Apiroam, R. (2015). Approaches for Human Capital Measurement with an Empirical Application for Growth Policy. Asian Social Science, 11(26), 309-322. https://doi.org/10.5539/ass.v11n26p309

UNDP. (2018). Technical notes: Calculating the human development indices-graphical presentation.Human Development Report 2016. UNDP

Wang, Y. (2018). Educational and nutritional consequences of education subsidy in rural China. China Economic Review, 51, 167-180. https://doi.org/10.1016/j.chieco. 2018.03.004

Yang, D. (2008). International migration, remittances and household investment: Evidence from Philippine migrants' exchange rate shocks. Economic Journal, 118(528), 591-630. https://doi.org/10.1111/j.1468-0297.2008.02134.x

Zadeh, L. A. (1965). Fuzzy Sets. Information and Control, 353, 338-353.

\section{APPENDIX}

Table 3. Human capital index of school-age population based on relative weight and AlkireFoster weight, 2017

\begin{tabular}{lclcl}
\hline \multirow{2}{*}{ Megency/ } & \multicolumn{2}{c}{ Relative Weight } & \multicolumn{2}{c}{ Alkire-Foster Weight } \\
\cline { 2 - 5 } Municipality & Index & Rank & Index & Rank \\
\hline Kep. Mentawai & 0.611099 & Low & 0.550128 & Low \\
Pesisir Selatan & 0.748999 & High & 0.666865 & Medium \\
Kab.Solok & 0.720547 & High & 0.645148 & Medium \\
Sijunjung & 0.717278 & High & 0.631925 & Low \\
Tanah Datar & 0.762353 & High & 0.684657 & Medium \\
Pdg. Pariaman & 0.768888 & High & 0.687833 & High \\
Agam & 0.776808 & High & 0.703651 & High \\
Lima Puluh Kota & 0.744785 & High & 0.664401 & Medium \\
Pasaman & 0.756942 & High & 0.677044 & Medium \\
Solok Selatan & 0.71456 & High & 0.634533 & Low \\
Dharmasraya & 0.739907 & High & 0.657419 & Medium \\
Pasaman Barat & 0.714282 & High & 0.626764 & Low \\
Padang & 0.861471 & Very High & 0.804703 & Very High \\
Kota Solok & 0.852612 & Very High & 0.787802 & Very High \\
Sawahlunto & 0.831419 & Very High & 0.760131 & High \\
Padang Panjang & 0.860474 & Very High & 0.803797 & Very High \\
Bukittinggi & 0.863972 & Very High & 0.807792 & Very High \\
Payakumbuh & 0.867252 & Very High & 0.811171 & Very High \\
Pariaman & 0.873121 & Very High & 0.812357 & Very High \\
\hline West Sumatera & 0.773437 & High & 0.700117 & High \\
\hline
\end{tabular}


Table 4. Human capital index of school-age population in West Sumatera by regency/ municipality, 2017

\begin{tabular}{|c|c|c|c|c|c|c|c|c|c|c|}
\hline $\begin{array}{c}\text { Regency/ } \\
\text { Municipality }\end{array}$ & IPP & $\begin{array}{c}\text { Having } \\
\text { Health } \\
\text { Insurance }\end{array}$ & $\begin{array}{c}\text { No } \\
\text { Smoking } \\
\text { Behavior }\end{array}$ & $\begin{array}{c}\text { Using } \\
\text { Internet }\end{array}$ & $\begin{array}{c}\text { Using } \\
\text { Computer }\end{array}$ & $\begin{array}{l}\text { Lighting } \\
\text { Source }\end{array}$ & $\begin{array}{c}\text { Drinking } \\
\text { Water } \\
\text { Source }\end{array}$ & $\begin{array}{c}\text { Cooking } \\
\text { Water } \\
\text { Source }\end{array}$ & Index & Rank \\
\hline Kep. Mentawai & 0.906 & 0.651 & 0.991 & 0.020 & 0.014 & 0.484 & 0.437 & 0.449 & 0.611 & 19 \\
\hline Pesisir Selatan & 0.937 & 0.430 & 0.982 & 0.164 & 0.264 & 0.944 & 0.768 & 0.718 & 0.749 & 12 \\
\hline Kab.Solok & 0.892 & 0.450 & 0.956 & 0.182 & 0.271 & 0.887 & 0.700 & 0.689 & 0.721 & 15 \\
\hline Sijunjung & 0.909 & 0.423 & 0.971 & 0.170 & 0.221 & 0.949 & 0.700 & 0.529 & 0.717 & 16 \\
\hline Tanah Datar & 0.924 & 0.576 & 0.976 & 0.186 & 0.308 & 0.939 & 0.752 & 0.683 & 0.762 & 10 \\
\hline Padang Pariaman & 0.938 & 0.541 & 0.992 & 0.186 & 0.287 & 0.967 & 0.732 & 0.732 & 0.769 & 9 \\
\hline Agam & 0.928 & 0.598 & 0.965 & 0.243 & 0.322 & 0.941 & 0.776 & 0.750 & 0.777 & 8 \\
\hline Lima Puluh Kota & 0.908 & 0.453 & 0.972 & 0.171 & 0.284 & 0.929 & 0.776 & 0.721 & 0.745 & 13 \\
\hline Pasaman & 0.895 & 0.907 & 0.973 & 0.138 & 0.173 & 0.863 & 0.652 & 0.638 & 0.757 & 11 \\
\hline Solok Selatan & 0.916 & 0.469 & 0.969 & 0.137 & 0.187 & 0.861 & 0.700 & 0.664 & 0.715 & 17 \\
\hline Dharmasraya & 0.897 & 0.374 & 0.966 & 0.189 & 0.266 & 0.953 & 0.763 & 0.788 & 0.740 & 14 \\
\hline Pasaman Barat & 0.915 & 0.475 & 0.964 & 0.110 & 0.124 & 0.893 & 0.702 & 0.670 & 0.714 & 18 \\
\hline Padang & 0.964 & 0.717 & 0.983 & 0.370 & 0.566 & 0.980 & 0.931 & 0.898 & 0.861 & 4 \\
\hline Kota Solok & 0.937 & 0.703 & 0.968 & 0.282 & 0.521 & 0.974 & 0.993 & 0.967 & 0.853 & 6 \\
\hline Sawahlunto & 0.936 & 0.751 & 0.965 & 0.288 & 0.408 & 0.987 & 0.910 & 0.800 & 0.831 & 7 \\
\hline Padang Panjang & 0.959 & 0.741 & 0.976 & 0.337 & 0.584 & 0.979 & 0.922 & 0.910 & 0.860 & 5 \\
\hline Bukittinggi & 0.943 & 0.709 & 0.957 & 0.376 & 0.588 & 0.990 & 0.979 & 0.951 & 0.864 & 3 \\
\hline Payakumbuh & 0.946 & 0.776 & 0.964 & 0.343 & 0.572 & 0.959 & 0.979 & 0.976 & 0.867 & 2 \\
\hline Pariaman & 0.945 & 0.953 & 0.966 & 0.324 & 0.517 & 0.989 & 0.887 & 0.897 & 0.873 & 1 \\
\hline West Sumatera & 0.925 & 0.601 & 0.972 & 0.215 & 0.327 & 0.921 & 0.783 & 0.750 & 0.773 & \\
\hline
\end{tabular}


Table 5. Detail of data of dimension indicator

\begin{tabular}{|c|c|c|}
\hline Dimension & Indicator & Data \\
\hline Education & IPP & Age minus year of schooling ${ }^{2}$ \\
\hline \multirow{4}{*}{ Health } & Having Health & 1. Yes \\
\hline & Insurance & 0. No \\
\hline & No Smoking & 1.Yes \\
\hline & Behavior & $0 . \mathrm{No}$ \\
\hline \multirow{26}{*}{ Housing } & & 1. PLN (State Electricity Company) \\
\hline & Lighting & 2. PLN Without Gauge \\
\hline & Resources & 3. Non PLN \\
\hline & & 4. Non Electricity \\
\hline & \multirow{11}{*}{$\begin{array}{c}\text { Drinking Water } \\
\text { Source }\end{array}$} & 1. Bottled Water \\
\hline & & 2. Reload Water \\
\hline & & 3. Tap Water \\
\hline & & 4. Artesian Water With Pump \\
\hline & & 5. Protected Artesian Water \\
\hline & & 6. Unprotected Artesian Water \\
\hline & & 7. Protected Fountain Water \\
\hline & & 8. Unprotected Fountain Water \\
\hline & & 9. Rain Water \\
\hline & & 10. Surface Water (River, Lake, Irrigation) \\
\hline & & 11. Other \\
\hline & \multirow{11}{*}{$\begin{array}{c}\text { Cooking Water } \\
\text { Source }\end{array}$} & 1. Bottled Water \\
\hline & & 2. Reload Water \\
\hline & & 3. Tap Water \\
\hline & & 4. Artesian Water With Pump \\
\hline & & 5. Protected Artesian Water \\
\hline & & 6. Unprotected Artesian Water \\
\hline & & 7. Protected Fountain Water \\
\hline & & 8. Unprotected Fountain Water \\
\hline & & 9. Rain Water \\
\hline & & 10. Surface Water (River, Lake, Irrigation) \\
\hline & & 11. Other \\
\hline \multirow{6}{*}{$\begin{array}{l}\text { Information } \\
\text { Technology }\end{array}$} & \multirow{4}{*}{ Internet Usage $^{3}$} & 1. Using internet to study \\
\hline & & 2. Using internet to finishing task \\
\hline & & 3. Using internet to send email \\
\hline & & 4. Using internet to other purposes \\
\hline & Computer Usage & 1.Yes \\
\hline & & 0. No \\
\hline
\end{tabular}

\footnotetext{
${ }^{2}$ For example, if 16 year old children attend junior high school in class 2, so year of school is 8 and age minus year of school $=16-8=8$

${ }^{3}$ Point $1-4$ have value 1 , if individual do all items so that the using internet indicator value is 4
} 
Table 6. Percentage of household based on indicators and working position

\begin{tabular}{lllll}
\hline \multirow{2}{*}{$\begin{array}{l}\text { Working } \\
\text { Position }\end{array}$} & \multicolumn{3}{c}{ Index = 1 } \\
\cline { 2 - 5 } & $\begin{array}{l}\text { Health } \\
\text { Insurance }\end{array}$ & Internet Usage & $\begin{array}{l}\text { Drinking Water } \\
\text { Source }\end{array}$ & Electricity \\
\hline Informal Sector & 56,09 & 9,90 & 48,39 & 87,56 \\
Formal Sector & 67,98 & 14,89 & 66,48 & 89,35 \\
\hline
\end{tabular}

Table 7. Regression variables

\begin{tabular}{ll}
\hline Variables & Description \\
\hline Income $(Y)$ & Household expenditure percapita \\
Fedu & Father years of schooling \\
Medu & Mother years of schooling \\
Hoccu & Head working sector \\
Hstatus & Head working position \\
Hsize & Number of household member \\
Gsub & Subsidies from government \\
UR & Urban-rural area \\
Gap1 & Father years of schooling < mother years of schooling \\
Gap2 & Father years of schooling = mother years of schooling \\
Gap3 & Father years of schooling > mother years of svhooling \\
\hline
\end{tabular}

